Research Article

\title{
The Middle School Teacher Resource Management Development
}

\author{
Ramang *, Juhriyansyah Dalle, Sulaiman \\ Master Program of Education Management, Universitas Lambung Mangkurat, Banjarmasin 70123, \\ Indonesia
}

Article history:

Submission November 2019

Revised September 2020

Accepted September 2020

${ }^{*}$ Corresponding author:

E-mail: hakamindah@gmail.com

\begin{abstract}
Teachers have the important tasks and roles, so that teacher resources must be developed. This study aims are to describe in-depth and analyze in detail about: (1) Management of teacher resource development, (2) The success of the management of teacher resource development, (3) Determinants of success and failure in realizing the management objectives of teacher resource development at SMAN 1 Katingan Hilir and SMPN 5 Katingan Hilir. Data in this study were collected through interviews, observations, and documentation. Analyzing data is done qualitatively. The results of this study indicate that SMPN 1 Katingan Hilir and SMPN 5 Katingan Hilir have made good management of teacher resource development in terms of achievement management, reward management, and training and development. In addition, this study also identified several determinants of success and failure of teacher resource management in the two schools. Hopefully, the results of this study can be used as material for consideration in implementing the management development of teacher resources in other school.
\end{abstract}

Keywords: Teacher resource, achievement management, reward management, training and development

\section{Introduction}

Teacher is the main subject that has an important role in education. According to Law Number 20 of 2003 concerning the National Education System which states that the task of teachers is to plan and implement the learning process, assess learning outcomes, conduct guidance and training and conduct community service research. In addition, the teacher also has an important.

Seen from the role side, Hamalik (2008) described that teacher has several roles as follow: (a) As a facilitator, which provides facilities for students to carry out learning activities? (b) As a guide, helping students overcome difficulties in the learning process; (c) As an environment provider, trying to create an environment that challenges students to carry out learning activities; (d) As a communicator, communicating with students and the community; (e) As a model, it is able to provide good examples for students to behave well; (f) As an evaluator, assessing student learning progress; (g) As an innovator, he helped disseminate efforts to reform the community; (h) As a motivator, increase enthusiasm and development of student learning activities; (i) As a cognitive agent, disseminating knowledge to students and society; (j) As an evaluation or evaluation, it is the most complex aspect of learning, because it involves a lot of backgrounds and relationships and other variables related to the context that are almost impossible to separate from each aspect of assessment; (k) To be able to carry out their duties and roles a teacher must have certain competencies. According to (Suriansyah, 2013) explains that the division of teacher competencies includes three aspects, namely;

How to cite:

Ramang. (2020). The middle school teacher management development. Journal of K6, Education, and Management, 3 (2), 138 - 148. doi: 10.11594/jk6em.03.02.05 
(1) Competencies in cognitive fields, namely competencies related to intellectual competencies such as knowledge about teaching methods, mastery of material, knowledge about learning and individual behavior, guidance and counseling knowledge and ways to evaluate children's learning; (m) Competence in the field of attitude, namely competence related to the readiness and availability of teachers for various rights relating to their duties and professions, such as the attitude of loving work and others; (n) Competence in the field of behavior, related to teacher's behavior / pregnancy, such as teaching skills, assessing, guiding, using assistive devices (educational technology) and communication with children.

Given the importance of tasks and roles, as well as the variety of competencies that teachers must have in carrying out their tasks, special efforts are needed in developing these competencies. So, later the teachers can carry out their tasks, roles and functions better. This means that, schools are required to carry out efforts to develop teacher resources owned. For this reason, researchers conducted research on the management of teacher resource development at SMPN 1 Katingan Hilir and SMPN 5 Katingan Hilir.The researcher took the location at SMAN 1 Katingan Hilir and SMPN 5 Katingan Hilir because the location was motivated by several considerations of uniqueness, attractiveness, and in accordance with the topics in this study, this location showed that the institute had implemented the development of teacher resources. The aim of this study is to describe in-depth and analyze in detail about (1) Management of teacher resource development at SMAN 1 Katingan Hilir and SMPN 5 Katingan Hilir which include; achievement management, reward management, and training and development; (2) The success of the management of teacher resource development at SMPN 1 Katingan Hilir and SMPN 5 Katingan Hilir which include; achievement management success, reward management success, and training and development success, (3) Determinants of success and failure in realizing the management objectives of teacher resource development at SMPN 1 Katingan Hilir and SMPN 5 Katingan Hilir which include; critical success factors, and failure critical factors.

\section{Material and Methods}

The location of this research is SMPN 1 Katingan and SMPN 5 Katingan Hilir. In addition, the research's data was gotten from:

\section{Interviewees (informant)}

The informants in this study were the principal, deputy headmaster, council of teachers, head of the administrative sub-section and selected teachers and other selected informants encountered in the field. The criteria for selecting the information were carried out using three sampling techniques, namely purposive, snowball, and internal sampling.

\section{Event or activity}

The event or activity under study is to find out how something is more certain because it has witnessed firsthand. For example, is the activities related to teacher resource development and how teacher participation and development activities. Here the researcher will see firsthand the events that occur related to the management of teacher resource development at SMAN 1 Katingan Hilir and SMPN 5 Katingan Hilir.

\section{Documentary}

Documents are the written materials or objects related to certain events and activities, whether in the form of written notes, records, pictures or objects relating to all matters relating to the management of teacher resource development at SMPN 1 Katingan Hilir and SMPN 5 Katingan Hilir.

The data collection was done with several techniques such as:

\section{Deep interview}

Interviews conducted in this study were indepth interviews with data subjects at SMPN 1 Katingan Hilir and SMPN 5 Katingan Hilir. The interview used is to find data related to the development of teacher resources. Researchers met directly with informants during the interview. The interviews were conducted according to the focus of the problem at the time the researchers were in the field, by conducting interviews with all informants to obtain data relating to the Management of Teacher Resource 
Development at SMPN 1 Katingan Hilir and SMPN 5 Katingan Hilir.

\section{Observation of the participants}

The main issues observed in this study are all the data that the process of implementing human resource development management activities in SMAN 1 Katingan Hilir and SMPN 5 Katingan Hilir from the stage of field data collection. General description of the school as a complement to the data based on a concrete research focus that is directly observed all activities related to the management of teacher resource development in SMPN 1 Katingan Hilir and SMPN 5 Katingan Hilir.

\section{Documentation}

Researchers examined documents owned by SMPN 1 Katingan Hilir and SMPN 5 Katingan Hilir. Among these documents were analyzed to understand the condition of SMPN 1 Katingan Hilir and SMPN 5 Katingan Hilir which were the background of the research which included: historical standing records and their development; school profile; relevant photographs; texts or records of official speeches related to education; decision letters and certificates of appreciation which form school documents; education map at the district, sub-district level; case notes; achievement book; list of teachers and staff; and so on that are considered to be related.

The data analysis technique on this research is divided into two different things; those are the on-site data analysis and the offsite data analysis.

\section{On-site data analysis}

In doing the on-site data analysis, there are several stages that could be done such as:

\section{a.Data reduction}

In reducing the data, researcher chosed and sorted data based on focus of the research; the initial data in the form of interview note will be simplified into several points which are easier to understand.

\section{b.Data Presentation}

The data display will help researcher in systemizing data in the clear form to be analyzed. This is done by reviewing data gotten and then making the actual systemic document about the teacher resource development management in SMPN 1 Katingan Hilir and SMPN 5 Katingan Hilir.

\section{c. Conclusion}

The researcher draws preliminary conclusions that are temporary and will change if no strong evidence is found to support the next stage of data collection. But if the conclusions found at an early stage, supported by valid and consistent evidence when researchers return to the field to collect data, then the conclusions put forward are credible conclusions.

\section{Cross site data analysis}

Cross-site data analysis is a process of comparing and combining the findings obtained from each site. Initially the findings obtained from SMAN 1 Katingan Hilir were arranged based on the theme, analyzed inductively conceptually and made narrative explanations arranged into certain propositions which were then developed into a substantive theory 1 . Findings from SMPN 5 Katingan Hilir were arranged as on the previous site and became substantive theory.

\section{Results and Discussion \\ Achievement management}

Planning in giving teacher achievement starts from planning for giving achievements according to the teacher's performance in classroom learning, student achievement in activities managed by the teacher, teacher achievement in the field and the acquisition of awards recognized by the government. Teacher achievement criteria include producing students who excel, winning educational competencies, making diktat, creating inventions and learning innovations, getting awards in the field of awards received from government and non-government, making papers in scientific journals including making research and carrying out tasks with good dedication. The awarding of performance is based on recommendations given by school principals in the form of higher-level office recommendations, recommendations as peer tutors, recommendations as trainers for teacher performance achievements in other 
development activities. Improving the quality of teachers must also collaborate or partner with stakeholders to produce optimal goals so that it involves all parties in a professional manner so as to foster a spirit of participation in teacher achievement.

Implementation of achievement in the form of exemplary teachers is done in semesters; motivation is carried out by the principal according to the needs of the agenda in the meeting. Evaluations conducted by the principal through the presence, performance, achievement, student development, other notes. Based on the results (Hallinger et al., 2014) of research, evaluations of teacher performance are very important in efforts to improve school quality. In addition, teacher evaluation also has a positive effect on teacher job satisfaction (Noor, 2019). In accordance with the results of research conducted by Bichi (2017), teacher evaluation is as important as student evaluation and plays an important role in sustainable school development.

The method used by school principals in determining teacher achievement is to supervise the class approach technical approach, discussion, and direct and indirect approaches. Evaluation is by conducting a Performance Assessment List (DP3) with a standardized evaluation format by the government. Whereas Management of achievement at SMPN 5 Katingan Hilir begins with a plan that is to make a cluster of study fields so that it can see the performance of teachers in learning. The effectiveness of teacher mastery in teaching and time discipline. Planning begins with an internal meeting with the school principal and viceprincipal and the committee. The organizing is carried out by forming a team of criteria for achieving teacher criteria conducted in a certain period as a reference for the school principal to make decisions in the achievement of teachers. Implementation in the achievement of teacher performance depends on student achievement, the provision of positions and additional assignments. Forms of achievement can be in the form of support and motivation, praise for teachers who excel and are able to improve the quality of education at SMPN 5 Katingan Hilir.
Supervision is carried out with indicators of teacher behavior that has achievements with ideal standards of educators, the professional image attached to it and the quality of students they educate. The evaluation carried out in an attempt to find benchmarks for giving future teacher achievements (Sunarno, 2015).

Based on the principal of the school/madrasah, among others, states that the competency of the principal and the school supervisor must have to provide guidance to teachers in carrying out classroom action research and other scientific work (Suriansyah and Aslamiah, 2014). The headmaster conducts the training of teachers in the school to improve his competence. The role of the principal's leadership is very important in increasing teacher professionalism. Research conducted by Josanov-Vrgovic and Pavlovic (2014) found that the principal's leadership style influenced job satisfaction of teachers in Sebia. Likewise with the results of research conducted by Cansoy (2019) who found that principals' leadership behavior affects the satisfaction of teachers in the school they lead. In addition to teacher job satisfaction, student success is also influenced by the principal's leadership style as reported in the results of the study (Baptiste, 2019).

Other research conducted by Abubakar et al., (2018) found that the principal's leadership also affected the work motivation of teachers. Research conducted in schools in Malaysia by Abdullah et al., (2018) also found that teachers' motivation to carry out their work in schools was greatly influenced by the transformation of leadership from the principal. In addition, the managerial ability of a school principal also has a stake in improving teacher performance (Fauzi et al., 2018).

From the results of these studies, it can be understood that school administration has an important role in improving the quality of teachers in schools. Teachers are one of the determinants of the high and low quality of education in schools. The success of the administration of education is very much determined by the extent to which the readiness of the teacher in preparing students through teaching and learning activities. A teacher is a professional educator with the 
main task of educating, directing, guiding, teaching, training, assessing and evaluating students in the formal education pathway (Suhaimi, 2018).

The development of teacher resources, in this case, is to improve teacher competencies that work efficiency of all teachers in the school. One way to provide achievement to teachers is by managing compensation carried out by both sites. The management of incentives designed aims to reward teacher work performance.

This agrees with Notoatmodjo (2003) namely the management of compensation of an organization must be arranged in such a way that it is a good system in organizations including school organizations. With a good compensation system objective will be achieved, including: respecting the work performance of employees, maintaining employee ways to work in the organization, ensuring fairness among employees in the organization, controlling costs to the organization, obtaining qualified employees, and meeting the rules or regulations which is a demand from the government or the public. In achieving the success of the management of teacher resource development, the provision of compensation based on teacher achievement also gives a good influence in improving the quality of education.

This opinion was also expressed by (Rahmawati and Ahmad, 2019) the management of compensation with the aim of providing stimulation and motivation to employees or workers to improve work performance, effectiveness, and efficiency of results. Compensation can be properly designed to achieve mutual success so that employees feel satisfied with their efforts and motivated to achieve common goals and objectives in organizations including schools.

This is in line with the opinion of Hasibuan (2008) the management of compensation is all income in the form of money, direct or indirect goods received by employees as compensation or services provided to the organization. Compensation programs aim at providing satisfaction for all parties should the compensa- tion program be established based on the principles of fair and reasonable, standard provisions that are set together and motivate someone to work hard.

\section{Reward management}

The salient finding on this site is rewarding done by the principal in planning conducted by analyzing teacher needs. The formulation of the goal of giving rewards to teachers. Efforts made in addition to planning development activities, by giving rewards to teachers through achievements in the school both from the teacher, students and the school itself. In a separate plan, analysis and identification of the needs of the development program are carried out for teachers that affect performance, both in compensation and incentives for teachers who excel.

Qualifications for giving rewards to teachers are based on loyalty, honesty, and example. Organizing is done by forming an assessment team based on achievement management, activities that have been followed by development activities that have been followed by teachers based on school archive data, teacher needs, and characteristics. The implementation of rewards can be in the form of compensation, incentives, additional assignments, further studies, positions, and certification. The data found on site 1 is in the form of salary, compensation, and data such as school principal's decree, the position given by the school principal and the committee's position.

Implementing rewards in the form of support, praise and motivation at each monthly meeting. Supervision of monitoring activities is obtained from direct observation when the principal conducts supervision in the classroom. Evaluations made on teachers who receive rewards are still being assessed performance, whether the rewards given are able to improve teacher performance and also the quality of education (Mahrita and Aslamiah, 2018). The management of rewarding at SMPN 5 Katingan Hilir begins with the planning of rewarding teachers through internal meetings with the deputy headmaster and the school 
committee. The factors that influence the provision of rewards are (1) the presence of teacher attendance, (2) completeness of teacher administration, 3) implementation of learning, (4) work performance, and (5) personality and social community.

The rewards given by the principal to teachers at SMPN 5 Katingan Hilir are (1) trust to occupy a position or assignment, (2) provide training opportunities, (3) facilitate the promotion process, (4) appreciation, (5) promotion. At the implementation stage, socialization of the reward is given, while the reward is in accordance with the wishes and needs of the teacher.

Supervision and evaluation carried out in reward management to foster awareness of teacher performance and continuously strive to develop abilities in carrying out their duties and obligations. Evaluation is based on the presence of teacher performance and innovation made by teachers to students.

According to the Teacher and Lecturer Law Number 14 of 2005 which requires teachers to be professional in teaching as evidenced by teacher certification, the form of giving rewards or awards for outstanding teachers given by schools can be in the form of certificates from schools. Schools provide assistance in the form of fees for teachers who carry out further studies. Through reward, management will improve teacher performance because basically, teachers feel happy when their work is valued let alone rewarded. According to Surya (2003) revealed that teacher professionalism is characterized by the embodiment of teachers who have: expertise, a sense of responsibility and a high sense of partnership.

Reward strategy is carried out in several stages. This is done because in the management of human resources in schools strategic planning is needed so that the steps and ways have taken can be successful. The stages of rewarding strategy or reward management start from the stage of determining the purpose of rewarding, determining the rewards that are in accordance with the teacher's performance, socializing with the teacher about the reward plan and implementing the reward program and finally evaluating the achievement of the reward. Research findings at both sites in the efforts of principals in fostering teacher performance by giving awards or rewards; Rewards given in the form of salary increases, granting positions, granting positions in the composition of the committee. This is in accordance with the opinion of Siagian (1987, p. 70) that a rational creature, a worker wants to get an award if the individual is considered successful in carrying out their duties. The award can be in the form of promotions, salary increases, awards in various forms.

The explanation of the provision of rewards at SMPN 1 Katingan Hilir is to determine the purpose of the reward program starting with the desired decisions or in accordance with the needs of the school. Through the formulation of clear objectives, schools can use teacher resources effectively. The aim at SMAN 1 Katingan Hilir is to improve teacher performance which will ultimately have an impact on improving school quality.

The giving of rewards at SMAN 5 Katingan Hilir is done with the formulation of clear objectives, while the form of rewards given is based on the wishes of the teacher when the socialization takes place through meetings. Giving rewards on both sites in accordance with the opinion of the Educational Administration Lecturer Team (2003) an educator development program is usually held on the assumption of various deficiencies seen from the demands of the organization or because of the will and need to grow and develop among educators with one of the principles namely the development of educators is carried out to encourage the increase in the contribution of each individual to the educational organization or the school system and to provide forms of rewards in welfare and incentives in return for ensuring optimal fulfillment of all socio-economic and social-psychological needs. The principal's policy in including teachers in the certification program is an act that helps teachers to obtain official recognition by the issuance of a charter/certificate as a professional teacher. With the encouragement and motivation of the school principal, teachers at SMPN 5 Katingan Hilir in preparing materials to take the certification exam, so that teachers who pass de 
jure certification are recognized by law as professional teachers (Normiati, 2019). Several studies have shown that giving rewards affects performance. Research conducted by Kathombe et al., (2018) at several universities in Kenya found that rewards in the form of both money and non-money had a positive and significant effect on the performance of lecturers and staff at universities in Kenya. Other studies that also found similar results were Muogbo and Cineze (2018) who conducted research at several Zenith Bank branch offices in Nigeria.

The results of his research show that giving both intrinsic and extrinsic reward gives a positive impact on the performance of workers. In addition, the results of his research also suggest that rewards are given according to the needs and desires of the workers so that they feel satisfied and give their best performance. Similar research was also conducted by Martono et al., (2018) who analyzed the management of rewards on the performance of educators and education staff at Semarang State University. Their results found that remuneration did not only affect performance but work motivation of educators and education staff at Semarang State University.

Furthermore, research conducted by Wangechi et al., (2018) who conducted research at the Nyeri County Government Office in Nigeria, where the results of the study showed that giving rewards can create job satisfaction and improve employee performance in the government office. Other research, carried out by Omuya (2018) also found that giving rewards and compensation had a positive effect on the performance of employees at Kenya Universities. Other research on rewarding in the form of remuneration in the world of education was also carried out by Joram et al., (2018), the results of his research found that remuneration has a significant influence on increasing the work commitment of employees.

\section{Training and development}

Training and development is an effort to improve teacher performance and competencies that are carried out on an ongoing basis so as to be able to create performance in accordance with the desired requirements. In addition, efforts to train and develop teacher resources are in accordance with the duties and functions of the teachers concerned at school (Rijani, 2018). The more often teachers participate in training and development, the closer they will be to achieving teachers to become competent teachers in carrying out their duties so that better teacher performance expectations will be achieved and in the end, the results will reach the quality of education at school institutions. Research conducted by Hervie and Winful (2018) at Ebenezer High School, Ghana found that training and development had a significant effect on the performance of teachers at the school.

Furthermore, Ali and Hamza (2018) who conducted research in Lahore, Pakistan found that teacher training affected student behavior and the development of school organizations. Not only in the school environment but providing training also plays an important role in improving the ability of human resources in the company environment. This can be seen from the results of research conducted by Imran and Tanveer (2015) in several banks in Pakistan. Their results showed that the implementation of training and development had a positive and significant impact on the performance of workers at these banks. Similar research conducted in the business world is research conducted by Kum et al., (2014) at Escon Consulting South Africa. Their results showed that the training was able to improve the work skills of workers in the company.

Minimum teacher standards must be in accordance with their respective fields in accordance with the Regulation of the Minister of National Education of the Republic of Indonesia No. 16 of 2007 concerning standards of academic qualifications and teacher competencies. As for achieving the predetermined standards, development and coaching for educators are needed in the form of seminars, workshops or training, education, workshops, symposiums, scientific works and so forth. Sagala (2009) workshop activities are expected to help teachers' problems in carrying out teaching and learning activities, which have 
characteristics including: (1) the problems discussed are life centered and arise from individual participants, (2) can foster the profession higher and better than before which also means that there is a change in themselves after participating in this activity, (3) held based on shared needs, (4) the method used in working is a method of solving problems of deliberation and inquiry, (5) always maintaining balanced life in addition to developing knowledge, changing behavior and skills, and (6) using resource persons the material resources that provide enormous assistance in achieving results

In order to improve teacher competency through the management of teacher resource development at SMPN 1 Katingan Hilir and SMPN 5 Katingan Hilir in the short term there are training and development programs both structural and functional in order to meet the needs of increasingly complex tasks and are based on the development of knowledge and technology. The effort taken is to hold training and development programs carried out off the job training and inhouse training. Besides giving assignments and leeway in teaching when attending training outside of school. Based on the findings of the management of teacher resource development in SMAN 1 Katingan Hilir it is known that in the framework of its management program it has good management, especially in planning by identifying training needs in improving the quality of education and also teacher development in learning innovations. Organizing is done to divide the tasks in determining teacher candidates who follow training and development. The implementation, supervision, and evaluation of the determinants of success and failure; This management stage aims to improve the quality and competence of teachers in teaching, personal and innovation development abilities. Findings at SMPN 5 Katingan Hilir at the planning stage were carried out by identifying teacher shortcomings and difficulties in teaching so that a development program was found that suited the teacher's needs. the program is right on target so that the material is tailored to the objectives and implementation of the program tailored to the needs. The budget used uses the principle of transparency and implementation and finally supervision of training activities and evaluation of research results that have been carried out.

Good planning is planning that includes: 1) made by people who understand and know correctly about the goals of the organization, 2) made by people who understand correctly good planning techniques, 3) cannot be separated from the thinking of the executor, 4) must be accompanied by a details, 5) flexible and flexible, 6) are simple, 7) plans for risktaking, 8) are practical, and 9) plans are predictions that approach the certainty (Suriansyah and Aslamiah, 2015).

Schools hold training or workshops that are tailored to the needs of teacher development by bringing in some pematetri from universities or related agencies. Whereas; for external training, the principal sends several teachers to attend seminars or workshops in accordance with their respective fields. MGMP is a program to develop teacher resources for similar subjects. The objectives of the MGMP by teachers at SMPN 5 Katingan Hilir are: 1) growing the ability and skills of teachers in learning, 2) equalizing the ability of teachers, 3 ) discussing the problems faced by teachers, 4) helping teachers in obtaining information in accordance with the eyes the lessons he learned, and 5) sharing information and experiences in order to follow and adjust to the development of science and technology.

The teacher resource development program that was followed by SMPN 1 Katingan Hilir and SMPN 5 Katingan Hilir is the collaboration with the Katingan Regency Educational Quality Assurance Institute. MGMP participants include both public and private SMP and MTs teachers and the implementation of the MGMP school is divided into groups of subjects whose meetings are scheduled once a month. The MGMP is carried out in turns, meaning that every MGMP participant school will get a turn in accordance with the specified schedule. Based on the findings in the field MGMP activities have been carried out well. School management ie the principal always informs the teacher and is responsible by providing substitute teachers when the subject 
teachers take part in MGMP activities. In accordance with the opinion of Daryanto (2011) School principals must be able to optimize and access school resources to realize their vision, mission, and goals. This can be realized by developing programs, utilizing the resources of teachers and education personnel, as well as utilizing school resources in a superior manner. In this case, the principal should be able to facilitate and provide broad opportunities for teachers to be able to carry out professional development activities through various education and training activities, both carried out at schools such as school-level MGMP / MGP, in-house training, professional discussion and so on. It can also be through education and training activities outside of school, such as opportunities to continue education or participate in various training activities organized by other parties.

\section{Determinants of success and failure}

As a formal educational institution in improving the quality of education in schools through the development of teacher resources, budget constraints are one of the factors causing failure, there are several development programs that have not been able to be implemented effectively. As a state school, SMPN 1 Katingan Hilir and SMPN 5 Katingan Hilir must manage the school budget properly, this is done with the finances used from the BOS funds as a free education policy which is a matter of activity both the cost of transporting teachers when participating in activities outside of school, program activities in schools that use other funds or use their own private teacher funds. In the findings at SMAN 1 Katingan Hilir in training and development activities, the school's effort is to use sponsors so that the activities can run smoothly. Supervision is carried out by the principal carried out routinely and has a schedule both to the teacher individually and to the teacher when doing learning.

The purpose of this supervision is to anticipate by looking at the extent of performance based on the achievements of the teacher, the rewards obtained by the teacher and the training and development that the teacher follows. so that when the teacher carries out the tasks and responsibilities assigned to the teacher, it is avoided to misuse the teacher's performance.

In the findings at SMPN 5 Katingan Hilir in an effort to develop teacher resources that still experience many obstacles in interest and support. Not all existing teachers join the development program but all of this depends on the teacher's perception. The need for motivation by the principal so that teachers can improve their performance both individually and in groups. This is in accordance with the opinion of Wibowo (2011) in building high performance, it requires cultural leader who is essentially a leader who experiences other people including the fact that other people can have different cultures.

Supervision carried out by principals in both situations uses top-down supervision, that is, supervision is carried out directly to subordinates and self-control supervision, which is inherent in the principal's supervision of activities carried out in developing teacher resources in schools. This supervision is more used as an example for teachers in schools to be able to introspect themselves and try to be a good example for colleagues and for teachers in other schools.

Observing the findings on the two sites, is in line with the opinion of Sagala (2000) that the supervision is carried out by the principal of the whole class whether teaching and learning activities occur. Then supervise the parties related to learning whether to really provide learning needs services. While the teacher supervises the program that he has determined whether it has been implemented or in accordance with the plan he set himself. If there is a mistake or there is a program that cannot be completed, an immediate improvement is made in the planning, so that the goals previously determined can be maximally fulfilled.

\section{Conclusion and Recommendation}

The results can be concluded that this study indicate that SMPN 1 Katingan Hilir and SMPN 5 Katingan Hilir have made good management of teacher resource development in terms of 
achievement management, reward management, and training and development. In addition, this study also identified several determinants of success and failure of teacher resource management in the two schools. Hopefully, the results of this study can be used as material for consideration in implementing the management development of teacher resources in other school.

\section{Acknowledgment}

Author especially grateful for principals, teachers and staff in SMPN 1 Katingan Hilir and SMPN 5 Katingan Hilir. Author wish to express with deep thanks to all the members of Dinas Pendidikan Kabupaten Katingan Hilir.

\section{References}

Abdullah, A. G., Ling, Y.-L., \& Sufi, S. B. (2018). Principal transformational leadership and teachers' motivation. Asian Education Studies, 3(1), 36-42. doi:10.20849/aes.v3i1.316

Abubakar, A.-M., Inuwa, B. B., \& Hamma, M. (2018). Principal leadership style towards teachers' motivation on secondary schools in Nigeria. Advances in Social Science, Education and Humanities Research, 125, 88-90. doi:10.13140/RG.2.2.22288.30722

Ali, R. K., \& Hamza, M. A. (2018). pImpact of teachers' training on students' learning attitude and organizational performance. The International Journal of Bussiness and Management, 6(10), 239-. Retrieved from www.theijbm.com

Atmodiwirio, S. (2001). Manajemen pendidikan Indonesia. Jakarta: Ardadzya Jaya.

Baptiste, M. (2019). No teacher left behind: The impact of principal leadership styles on teacher job satisfaction and student success. Journal of International Education and Leadership, 9(1), 1-11.

Bichi, A. A. (2017). Evaluation of teacher performance in schools: Implication for sustainable development goals. Northwest Journal of Educational Studies, 2(1), 103-113.

Cansoy, R. (2019). The Relationship between school principals' leadership behaviours and teachers' job satisfaction: A systematic review. International Education Studies, 12(1). doi:10.5539/ies.v12n1p37

Daryanto. (2011). Kepala sekolah sebagai pemimpin pembelajaran. Yogyakarta: Gava Media.

Fauzi, M., Syafrudin, \& Rokhmat, J. (2018). Principal's managerial skill in improving teachers' performance. IOSR Journal of Research \& Method in Education, 8(3), 77-81. doi:10.9790/7388-0803047781
Ford, T. G., \& Urick, A. (2018). Exploring the effect of supportive teacher evaluation experiences on U.S. teachers' job satisfaction. education policy analysis archives, 26(59), 136. doi:10.14507/epaa.26.3559

Hallinger, P., Heck, R. H., \& Murphy, J. (2014). Teacher evaluation and school improvement: An analysis of the evidence. International Journal of Policy, Practice and Research, 4(3). doi:10.1007/s11092-013-9179-5

Hamalik, O. (2008). Perencanaan pembelajaran berdasarkan pendekatan sistem. Jakarta: Bumi Aksara.

Hasibuan, M. S. (2014). Manajemen: dasar, pengertian dan masalah. Jakarta: Bumi Aksara.

Hervie, D. M., \& Winful, E. C. (2018). Enhancing teachers' performance through training and development in Ghana education service (A case study of Ebenezer Senior High School). Journal of Human Resource Management, 6(1), 1-8. doi:10.11648/j.jhrm.20180601.11

Imran, M., \& Tanveer, A. (2015). Impact of training dan development on employees' performance in Banks of Pakistan. European Journal of Training and Development Studies, 3(1), 22-44.

Janawi. (2011). Kompetensi guru citra guru profesional. Bandung: Alfabeta.

Joram, M. L., Wanjala, G., \& Matula, D. P. (2018). Institutional factors influencing teachers' job commitment in public primary schools. International Journal of Education and Research, 6(4), 1-17.

Josanov-Vrgovic, I., \& Pavlovic, N. (2014). Rellationship between the school pricipal leadership styles and teachers' job satisfaction. Montenegrin Journal of Economics, 10(1), 4357.

Kathombe, M. W., Kipchumba, S., \& Kirui, K. (2018). Reward management strategies and employee performance in selected Universities in Nakuru County, Kenya. Journal of Human Resource Management, 6(3), 95-102. doi:10.11648/j.jhrm.20180603.12

Kum, F. D., Cowden, R., \& Karodia, A. M. (2014). The impact of training and development on employee performance: A case study of Escon Consulting. Singaporean Journal of Business Economics, and Management Studies, 3(3), 72-105.

Martono, S., Khoiruddin, M., \& Wulansari, N. A. (2018). Remuneration reward management system as a driven factor of Employee Performance. International Journal of Business and Society, 19(4), 535-545.

Menteri Negara Pendayagunaan Aparatur Negara dan Reformasi Birokrasi. (2009). Peraturan Menteri Negara Pendayagunaan Aparatur Negara dan Reformasi Birokrasi Nomor 16 Tahun 2009 tentang Jabatan Fungsional Guru dan Angka Kreditnya. Jakarta: Kementerian Negara Pendayagunaan Aparatur Negara dan Reformasi Birokrasi Republik Indonesia. 
Menteri Pendidikan dan Kebudayaan. (2014). Peraturan Menteri Pendidikan dan Kebudayaan Nomor 67 tahun 2014 tentang Pejabat Penilai dan Atasan Pejabat Penilai Prestasi Kerja Pegawai negeri Sipil di Lingkungan Kementerian Pendidikan dan Kebudayaan. jakarta: Kementerian Pendidikan dan Kebudayaan.

Muogbo, U., \& Cineze, J. (2018). Effective reward management as a tool for improving employee performance in a private sector organisation (A Study Of Selected Zenith Bank Branches in Nigeria). International Journal of Humanities and Social Science Invention, 7(4), 106-117. Retrieved from www.ijhssi.org

Notoatmojo, S. (2003). Pengembangan sumber daya manusia. Jakarta: Rineka Cipta.

Omuya, J. M. (2018). Tne influence of compensation and rewards on employee performace in Public Universities in Kenya. International Journal of Economics, Commerce and Management, 6(3), 700-736.

Presiden Republik Indonesia. (2003). Undang-Undang Republik Indonesia Nomor 20 Tahun 2003 tentang Sistem Pendidikan Nasional. Jakarta: Pemeritah Republik Indonesia.

Presiden Republik Indonesia. (2007). Undang-Undang Republik Indonesia No. 14 Tahun 2007 tentang Guru dan Dosen. Jakarta, Indonesia: Negara Kesatuan Republik Indonesia.
Rachmawati, I. K. (2008). Manajemen sumber daya manusia. Yogyakarta: Andi Press.

Sagala, S. (2000). Administrasi pendidikan kontemporer. Bandung: Alfabeta.

Sagala, S. (2009). Manajemen strategik dalam peningkatan mutu pendidikan. Bandung: Alfabeta.

Siagian, S. P. (1987). Pengembangan sumber daya manusia. Jakarta: Gunung Agung.

Suriansyah, A., \& Aslamiah. (2014). Strategi kepemimpinan kepala sekolah, guru, orang tua, dan masyarakat dalam membentuk karakter siswa. Jurnal Cakrawala Pendidikan, 2(2), 234-247.

Tim Dosen Administrasi Pendidikan. (2003). Pengelolaan pendidikan. Bandung: Administrasi Pendidikan FIP UPI.

Wangechi, B., Kiragu, D., \& Sang, A. (2018). Role of reward systems on job satisfaction of employees in the County Government of Nyeri, Kenya. International Journal of Academic Research in Accounting, Finance and Management $\quad$ Sciences, 196-204. doi:10.6007/IJARAFMS/v8-i1/4045

Wibowo. (2011). Budaya organisasi: Sebuah kebutuhan untuk meningkatkan kinerja jangka panjang. Jakarta: Rajawali Press. 